\title{
Condition of Community Forest Management in Ternate Isle
}

\author{
Maulidya M. Umalekhoa ${ }^{1, *}$, Much. Hidayah Marasabessy ${ }^{1}$, \\ Firlawanti Lestari Baguna ${ }^{1}$
}

${ }^{1}$ Department of Forestry, Faculty of Agriculture, Khairun University, Ternate, Indonesia

*Corresponding author.Email: maulidyamayasari77@gmail.com

\begin{abstract}
Community Forest are usually called $\mathrm{HKm}, \mathrm{Hkm}$ has obtained a concession in a protected forest area since 2013. This study aims to determine the condition of Community Forest management by Community Forest farmer groups in protected forests on Ternate Isle. The method used was observation and interviews with forest farmer groups managing the Community Forest in Ternate Isle. Analysis of the data used is descriptive analysis and scoring for the assessment of community forest conditions based on safety, technical and economic aspects. The results showed that the Community Forest in the Tunas Muda farmer group was based on the safety aspect in the moderate condition (score at 26.43), the technical aspect was dependent on the moderate condition (21.86) and the economic aspect was in the bad condition (4.57). Ake Guraci farmer groups are based on safety aspects (28.00), technical aspects depend on moderate conditions (21.86) and economic aspects depend on bad conditions (score at 6.57). Rubahongi farmer groups based on safety aspects depend on moderate conditions (score at 28.71), technical aspects depend on moderate conditions (score at 24.14) and economic aspects depend on moderate conditions (score at 10.29) Community Forest in Ternate Isle.
\end{abstract}

Keywords: Community Forest, management, protected forest

\section{INTRODUCTION}

Ternate Isle of North Maluku Province is one of the areas that has received a Business Forest Utilization Business License (IUPHKm) for 35 years. Business licenses for the Utilization of Community Forests or IUPHKm in Ternate Isle are stipulated in the Gunung Gamalama Protected Forest area, based on a decree of the Minister of Forestry concerning the determination of the Community Forest working area on Ternate Isle, North Maluku Province [1].

IUPHKm was located in three subdistricts in Ternate Isle, namely Tunas Muda Forest Farmer Group in Tubo Kelurahan, North Ternate District, Rubahongi Farmer Group in Maliaro Kelurahan, Middle Ternate District, and Ake Guraci Farmer Group in Marikurubu Subdistrict, Ternate Tengah District with a total area of 290 ha [2]. The Community Forest Utilization Business licenses (IUPHKm) are an effort from the government to involve the community around the forest as partners in forest management. Community Forestry gives forest management permits to people who live around forests whose lives depend on forest products to manage forests sustainably [3].

Farmer groups manage Community Forestry in protected forest areas on Ternate Isle, management was based on local knowledge and community traditions while taking into account applicable laws and regulations, and can achieve economic and ecological goals. Community Forest
Management can prosper the community around the forest and can preserve the forest. Therefore, this research is aimed at looking at community forest management based on institutional, technical and ecological aspects by farmer groups in protected forests on Ternate Isle.

\section{METHODS}

The research took place in three locations of the Community Forest, namely the Tunas Muda farmer group, the Ake Guraci farmer group, and the Rubahongi farmer group. The study was conducted during May - July 2019. The sample in this study was a group of farmers managing the Community Forest on Ternate Isle, with a saturated sampling technique (census). Data collection using interview techniques with questionnaires and observations. Data collected were analyzed using tabulation frequency distribution and score analysis. Tabulation and score analysis are used to determine the condition of community forest management based on interval and score values. Determination of the interval using a formula with 3 (three) types of categories as follows;

$$
I=\frac{N T-N R}{K}
$$

Note: $\mathrm{I}=$ interval; NT = Highest Value; NR = Lowest Value; $\mathrm{K}$ = Class Category (Good, Moderate, Bad).

The evaluation of community forest conditions according to management aspects adjusts to the condition of the 
interval class in the calculation of the total score in several classes of good, moderate and bad categories in management aspects of IUPHHKm presented in Table 1.

Table 1. Determination of class scores based on the number of class intervals

\begin{tabular}{|c|c|c|c|c|}
\hline No & $\begin{array}{c}\text { Aspect } \\
\text { Management }\end{array}$ & Score & Interval & Condition \\
\hline \multirow{3}{*}{1} & \multirow{3}{*}{ Institutional } & \multirow{3}{*}{40} & $28-40$ & Good \\
\hline & & & $14-27$ & Moderate \\
\hline & & & $0-13$ & Bad \\
\hline \multirow[t]{2}{*}{2} & \multirow[t]{2}{*}{ Technique } & \multirow[t]{2}{*}{40} & $\begin{array}{l}28-40 \\
14-27 \\
\end{array}$ & $\begin{array}{l}\text { Good } \\
\text { Moderate }\end{array}$ \\
\hline & & & $0-13$ & Bad \\
\hline \multirow{3}{*}{3} & \multirow{3}{*}{ Economic } & \multirow{3}{*}{20} & $14-20$ & Good \\
\hline & & & $7-13$ & Moderate \\
\hline & & & $0-6$ & $\mathrm{Bad}$ \\
\hline & Total & 100 & & \\
\hline
\end{tabular}

\section{RESULTS AND DISCUSSION}

\section{A. Institutional Aspects}

The results of the analysis of forest management conditions based on institutional aspects in the Tunas Muda Forest Farmer Group, Ake Guraci Forest Farmer Group, and Rubahongi Forest Farmer Group are presented in Figure 1.

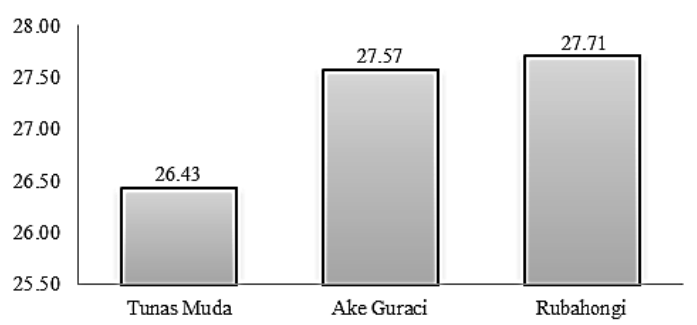

Figure 1. The score of the community forest management condition is based on the institutional aspects in Ternate Isle.

Figure 1 shows the condition of community forest management in Ternate Isle based on safety aspects, Tunas Muda forest farmer groups based on moderate conditions (score $<27$ ). The Ake Guraci forest farmer group is in good condition (score $>27$ ) and the Rubahongi forest farmer group depends on good condition (score $>27$ ).

This condition shows several indicators that have not been fulfilled in the management of Community Forests such as the unavailability of a secretariat, no financial administration documents, no moderate-term plans, a lack of human resources and no cultivation blocks. The category of Community Forest management in protected forests based on institutional aspects is in moderate and good condition.

\section{B. Technical Aspects}

The results of the analysis of forest management conditions based on technical aspects at the Tunas Muda Forest Farmer Group, Ake Guraci Forest Farmer Group, and Rubahongi Forest Farmer Group are presented in Figure 2.

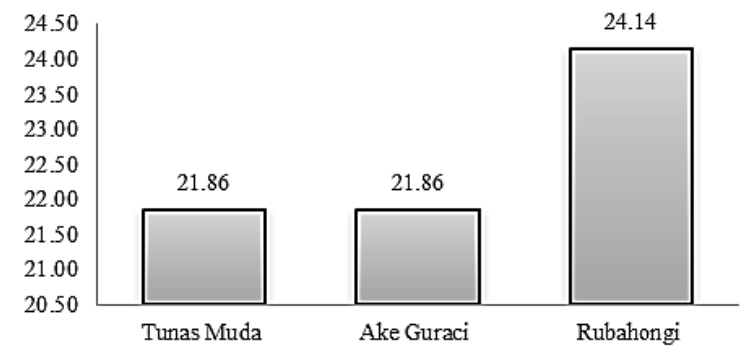

Figure 2. The score of the community forest management condition is based on the technical aspects in Ternate Isle.

Figure 2 shows the condition of Community Forest management based on the technical aspects of the Tunas Muda farmer group being in a moderate condition (score $<27$ ). The Ake Guraci farmer group is in the moderate condition $(<27)$ and the Rubahongi farmer group is in moderate condition $(<27)$. The average score for the condition of community forest management based on technical aspects is in a moderate condition. However, based on the acquisition of the highest score in the management of Community Forests, there is in the Rubahongi farmer group with a score of +24 in accordance with the evaluation of indicators on technical aspects.

Some indicators that are technically unfulfilled in community forest management are land rehabilitation at a slope of $50 \%$ using no strips of grass (rorak or gulud), no planting of endemic plant species, no planting of land cover crop types, no internal control of at least $1 \mathrm{x} /$ year, all group members do not participate in internal control, all group members do not pay the Forest Resources (SDH) provision, there are no land-use plans in the Community Forest and there is no control system plan in Community Forest management.

Rehabilitation and conservation in community forests are needed in addition to functioning to regulate and reduce the flow of water. According to Government Regulation No. 6 of 2007 concerning Forest Management and Preparation of Forest Management Plans and Forest Utilization, slope locations must use soil and water conservation techniques in forest management [4].

The existence of plants under the stand, it will reduce the rate of surface runoff that causes erosion. In addition, it can help increase people's income from the community forest. Plants that are able to grow cover crops will help efforts to provide livestock feed so that people can still rely on their income from the forest through livestock development. 
The category of Community forest management condition based on technical aspects is in moderate condition. This condition shows that technically the forest farmer groups do not understand clearly the technical arrangements related to community forest management. So the need for more intensive assistance.

\section{Economic Aspects}

The results of the analysis of forest management conditions based on economic aspects in the Tunas Muda Forest Farmer Group, Ake Guraci Forest Farmer Group, and Rubahongi Forest Farmer Group are presented in Figure 3.

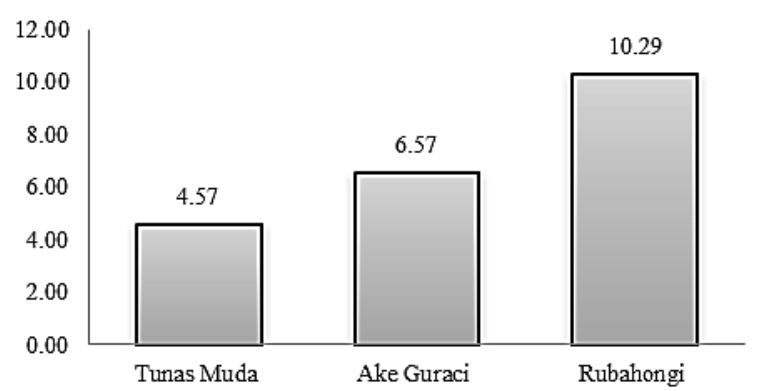

Figure 3. The score of the community forest management condition is based on the institutional aspects in Ternate Isle.

Figure 3. shows the average condition of the three forest farmer groups based on economic aspects, the management of Community Forests in protected forests on Ternate Isle is in a moderate condition. However, based on the indicators in each group there are farmer groups with bad economic conditions. Tunas Muda farmer groups are in bad condition (score 0-13). The Ake Guraci farmer group is in bad condition (score 0-13) and the Rubahongi farmer group is in bad condition (0-13).

Based on several indicators of Community Forest management activities in forest farmer groups have not been able to create additional sources of livelihood derived from the use of forest products, the absence of household cash income and non-cash income, the absence of facilities from non-governmental organizations in the development of social forestry business groups, no capital assistance from non-governmental organizations, lack of diversification of group economic ventures, lack of commercial utilization of non-timber forest products (NTFPs), absence of commercial use of environmental services, community forest management is not the main occupation for groups and the absence of products produced from the Social Forestry Business Group is usually called KUPS (Kelompok Usaha Perhutanan Sosial). The income from the Community Forest has not been able to meet the needs of the respondent's household and the respondent has another job outside of the farmer [5].
This shows that the condition of community forest management based on economic aspects is in bad condition. This condition will affect the income of farmers. Small income will affect community forest management. Therefore an increase in human resource capacity in managing forest products is needed. Increased skills to process forest products into higher value products and develop knowledge to manage and promote community-based ecotourism in protected forests managed by Community Forestry groups [6]. According to FAO, the concept of participatory forest management can create economic benefits for people who depend on forests and can create employment opportunities through forest farming groups [7].

\section{CONCLUSION}

The condition of community forest management on Ternate Isle in each forest farmer group based on the institutional aspect is in the medium condition, the technical aspect is in the moderate condition and the economic aspect is in a bad condition.

\section{ACKNOWLEDGMENT}

We are grateful to Departemen of Forestry, Faculty of Agriculture, Universitas Khairun Ternate, KPH Ternate Tidore, Tunas Muda, Ake Guraci and Rubahongi Farmer's Groups.

\section{REFERENCES}

[1] Surat keputusan Menteri Kehutanan Nomor: SK 426/Menhut-II/2013. Tanggal 12 Juni 2013 tentang penetapan areal kerja Hutan Kemasyarakatan di Pulau Ternate Provinsi Maluku Utara.

[2] POKJA PPS [Kelompok Kerja] Provinsi Maluku Utara. 2017. Profil Perhutanan Sosial Maluku Utara.

[3] Hari Kaskoy, Abrar Juhar Mohammed, and Makoto Inoue. 2014. Present State of Community Forestry (Hutan Kemasyarakatan/HKm) Program in a Protection Forest and Its Challenges: Case Studi in Lampung Province, Indonesia. Journal Forest and Sciense. Vol. 30. No. 1.

[4] Peraturan Pemerintah Republik Indonesia Nomor 6 Tahun 2007 tentang Tata Hutan dan Penyusunan Rencana Pengelolaan Hutan serta Pemanfaatan Hutan

[5] Ryke Nandini, Ambar Kusumandari, Totok Gunawan and Ronggo Sadono. 2016. Impact of Community Forestry Policy on Farmers in Rinjani Protected Forest Area. Journal of Economics and Policy. Vol. 9 (1) (2016): 34-49.

[6] Christine Wulandari and Heni Kurniasih. 2019. Community Preferences for Social Forestry Fasilitation Programming in Lampung Indonesia. Journal Forest and Society. Vol 3(1): 114-132, April 2019. 
[7] FAO [Food Agriculture Organization of The United Nations]. Socio-Economic Evaluation of Community-Based Forest Enterprise Development using the Market Analysis and Development Approach in Community Forestry in the Gambia.
By K.Camara. Forestry Policy anf Institutions Working Paper No. 27. Rome. 